\title{
CONTEXTUAL LEARNING IN ELEMENTARY SCHOOL: A META ANALYSIS
}

\author{
I Nyoman Indhi Wiradika ${ }^{1}$, Heri Retnawati ${ }^{2}$ \\ ${ }^{1,2}$ Postgraduate Program, Yogyakarta State University, Indonesia
}

\begin{tabular}{|c|c|}
\hline Article Info & ABSTRACT \\
\hline Article history: & \multirow{6}{*}{$\begin{array}{l}\text { The practice of contextual learning in Indonesia is a method that is often used. This } \\
\text { study aims to determine the average value of elementary school students with contex- } \\
\text { tual learning. Meta-analysis is used to calculate the average score of elementary school } \\
\text { students with contextual learning. The scope of the article is a contextual learning re- } \\
\text { search conducted on elementary school students in Indonesia. The publication year is } \\
\text { limited to } 2016 \text { to } 2021 \text {. This study uses } 44 \text { data sources for articles and theses with } \\
\text { the result that the aggregate proportion of students who complete their studies with } \\
\text { contextual learning is around } 79.25 \text {. These results prove that contextual learning can } \\
\text { obtain learning outcomes above the national minimum completeness criteria. }\end{array}$} \\
\hline Received: 21-07-2021 & \\
\hline Revised: 31-08-2021 & \\
\hline Published: 30-09-2021 & \\
\hline Keywords: & \\
\hline CTL & \\
\hline
\end{tabular}

Primary schoo

Meta Analysis

This is an open access article under the CC BY-SA license.

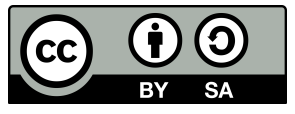

\author{
Corresponding Author: \\ I Nyoman Indhi Wiradika, \\ Postgraduate Program, Yogyakarta State University, \\ Jl. Colombo No.1 Yogyakarta, Indonesia \\ Email: inyoman2020@student.uny.ac.id
}

\section{INTRODUCTION}

Learning is an activity carried out with the aim of gaining knowledge, mastering certain competencies and shaping student attitudes. Learning success can be seen from changes in student behavior and learning outcomes (Puspitarini \& Hanif, 2019). Carrying out the learning process requires certain strategies and methods so that the objectives of learning can be achieved. Primary school students have different characteristics and learning processes from adults (García, Rodríguez, González-Castro, González-Pienda, \& Torrance, 2016). Learning in elementary schools requires certain efforts that are in accordance with the characteristics of the child. Usually, learning in elementary schools includes activities that actively involve students.

The process of choosing to use certain methods and approaches is not an easy decision for teachers. The use of a learning approach needs to be adapted to the characteristics of students, materials, learning environment and the availability of learning support tools. Using learner-centred learning approaches such as active learning, experiential learning, online learning, and the like in transformative learning can lead to deeper and meaningful learning. Fernando \& Marikar (2017), argues that the traditional lecture teaching method should be combined with participatory teaching methods such as question and answer and group discussions to produce an active learning experience.

Contextual learning is the most effective way for students to see the relationship between what students learn in the classroom and the real world (Scans, 2000). As stated by Kalchik and Oertle (2010), the Contextualized Teaching and Learning (CTL) approach is based on constructivist educational theory because it involves students and teachers in active classroom activities, ensuring that learning is student-centered and engaging. It is based on the idea that students create the meaning of their own concepts when learning through experiences that promote innate motivation and desire to learn. 
The use of contextual learning in learning can facilitate students to learn according to their needs and culture. Contextual learning is in accordance with the Indonesian context which has a variety of cultures and habits that lead to ways of producing knowledge. Bumgarner (2017) explained that the Contextualized Teaching and Learning (CTL) Approach is rooted in a constructivist approach to teaching and learning. The constructivist theory that students learn concepts and construct meaning through the interaction and interpretation of events in their environment. Contextualized Teaching and Learning (CTL) approach as mentioned by Satriani et al. (2012) is a learning philosophy that emphasizes the interests and experiences of students. It provides a means to achieve learning goals and objectives that require higher order thinking skills.

Contextual Teaching and Learning (CTL) is a learning approach that utilizes problems or problems of everyday life that exist around students as learning objects (Khotimah \& Masduki, 2016). The contextual teaching and learning approach is a promising set of strategies and practices that actively engage learners to promote and enhance learning and skills development. Learning can improve student learning outcomes and achievement (Qudsyi, 2017). The results of the research by Seifert and Sutton (2009) show that Motivation Theory also focuses on the students' perceived value of the instructional mode and the development of selfefficacy which is a key component of the Contextualized Teaching and Learning (CTL) Approach. Pupils are encouraged to reflect on their own ideas and experiences in which instruction and materials are embedded. Thinking about content in real-world experiences is important in the CTL Approach because students see the real-world relevance of what they are learning. So, they become interested and motivated.

There are seven principles contained in contextual learning; constructivism, inquiry, questioning, community learning, modeling, reflection, and authentic assessment (Nursanti, Putra, \& Manuaba, 2020). Meanwhile, according to Johnson (2008), there are seven learning components that form the basis of application, namely: 1) constructivism; 2) ask; 3) find; 4) learning community; 5) modeling; 6) reflection; and 7) actual assessment. The use of CTL in learning is ideally based on the stages that characterize contextual learning. The problem with contextual learning is the teacher's ability to reflect on learning and relate it to the environment. In addition, teachers do not yet have confidence in the importance of contextual learning in learning. This article tries to dig up information about contextual learning practices in elementary schools. A meta-analysis study was conducted to obtain a portrait of contextual learning practices and their implications for student learning outcomes.

\section{RESEARCH METHOD}

This research is a meta-analysis research that focuses on contextual learning in elementary schools. The sample in this study was obtained using the Publish or Perish 7 software. Some of the keywords used to obtain the data are summarized in Table 1.

Table 1. Keywords to obtain data

\begin{tabular}{c}
\hline Key Word \\
\hline CTL Elementary School \\
Elementary School Contextual \\
\hline
\end{tabular}

The database search was focused on Google Scholar, the UNNES Repository, and the Undiksha Repository. The criteria for the year of publication of the data sources are from 2016 to 2021. The types of data sources come from research publications in the form of scientific articles published in journals, and final assignments for elementary school teacher education students. The number of samples in this study were 44 data sources consisting of 31 journal articles and 13 theses.

The data used in this study were generated from quasi-experimental research and the data source was focused on the post-test experimental class. The results of the analysis used are the average score, standard deviation, number of samples and maximum and minimum scores. The data were analyzed using JASP 0.14.1.0 software with the Restricted ML method. In the description of the concentration measure, there is only one variable that is the keyword. The analytical technique used in this study uses a meta-analysis of the concentration measure. The use of convergence measures needs to pay attention that the analyzed studies measure the same thing, or measure the same variables (Retnawati, Apino, Kartianom, Djidu, \& Anazifa, 2018). 


\section{RESULT AND DISCUSSION}

The results of descriptive analysis show information about data sources. The data source contains information from the research sample which is categorized based on the period of publication, the respondent's class level, and learning outcomes from contextual learning. The following consists of the category of year of publication, class level of research participants, and learning outcomes from the use of contextual learning.

Table 2. Number of descriptive data source categories

\begin{tabular}{|c|c|c|c|}
\hline \multicolumn{2}{|c|}{ Category } & Number & Percentage \\
\hline \multirow[t]{6}{*}{ Publish Year } & 2016 & 2 & $5 \%$ \\
\hline & 2017 & 9 & $20 \%$ \\
\hline & 2018 & 5 & $11 \%$ \\
\hline & 2019 & 10 & $23 \%$ \\
\hline & 2020 & 17 & $39 \%$ \\
\hline & 2021 & 1 & $2 \%$ \\
\hline \multirow[t]{4}{*}{ Class } & 1 & 1 & $2 \%$ \\
\hline & 3 & 5 & $14 \%$ \\
\hline & 4 & 17 & $40 \%$ \\
\hline & 5 & 20 & $47 \%$ \\
\hline \multirow[t]{7}{*}{ Learning Outcomes } & Bahasa Indonesia & 2 & $5 \%$ \\
\hline & PKn & 5 & $11 \%$ \\
\hline & Matematika & 12 & $27 \%$ \\
\hline & IPA & 15 & $34 \%$ \\
\hline & IPS & 3 & $7 \%$ \\
\hline & Tematik & 6 & $14 \%$ \\
\hline & Kebudayaan & 1 & $2 \%$ \\
\hline
\end{tabular}

Based on Table 2, 39\% of data sources were published in 2020. The class that was the subject of the study was $47 \%$ of 5 th grade elementary school students. Learning outcomes that become the output of the use of contextual learning approaches $34 \%$ in science subjects.

The results of the calculation of Effect Size and Standard Error are obtained from identifying the number of samples, the average and standard deviation of the research results. The range of scores for each research result is equalized to a score of 0 to 100. Proportion and mean are measures or parameters that express the expectations of a sample or population. This parameter describes the position or location of a data in a range, between the minimum and maximum of a measured variable (Retnawati et al., 2018).

Table 3. Effect Size and Standard Error

\begin{tabular}{lcc}
\hline Research & ES & SE \\
\hline Nuryanto, et al. (2018) & 66.33 & 1.71 \\
Wulandari, et al. (2019) & 68.55 & 2.26 \\
Santoso (2017) & 70.00 & 2.67 \\
Mawardi, et al. (2019) & 69.44 & 2.39 \\
Mawardi, et al. (2019) & 70.43 & 1.36 \\
Wahidah, et al. (2019) & 71.50 & 2.17 \\
Astuti, et al. (2018) & 70.67 & 2.50 \\
Astutik (2021) & 74.54 & 1.52 \\
Herfiani \& Syarifuddin (2018) & 75.16 & 1.79 \\
Natalia, et al. (2017) & 75.26 & 2.15 \\
Asniah, et al. (2020) & 76.40 & 1.15 \\
Hasnidar \& Elihami (2020) & 75.81 & 0.57 \\
Anggreni, et al. (2017) & 76.22 & 1.72 \\
Adviani, et al. (2017) & 77.87 & 1.13 \\
Kartika \& Wulandari (2019) & 78.08 & 1.21 \\
Latifah \& Sa'odah (2019) & 78.20 & 1.79 \\
Sari, et al. (2019) & 78.41 & 2.28 \\
\hline
\end{tabular}


Table 3. Effect Size and Standard Error

\begin{tabular}{lcc}
\hline Research & ES & SE \\
\hline Saifuddin \& Nugraheni (2020) & 78.41 & 0.66 \\
Anjani, et al. (2020) & 78.50 & 1.71 \\
Setiawan (2020) & 79.00 & 1.00 \\
Mandasari, et al. (2019) & 79.31 & 0.51 \\
Yesya, et al. (2018) & 79.36 & 1.85 \\
Framita, et al. (2018) & 79.81 & 1.71 \\
Farida, et al. (2017) & 79.83 & 1.63 \\
Purwanti, et al. (2017) & 80.07 & 1.61 \\
Antari, et al. (2020) & 80.79 & 1.19 \\
Tinja, et al. (2017) & 81.00 & 1.36 \\
Ihsani, et al. (2018) & 81.00 & 1.23 \\
Nilasari, et al. (2016) & 82.27 & 2.38 \\
Harsanti (2017) & 82.37 & 1.02 \\
Safitri \& Trimurtini (2020) & 82.40 & 1.59 \\
Nursanti, et al. (2020) & 82.78 & 1.22 \\
Somayana (2020) & 83.50 & 1.32 \\
Sudira, et al. (2020) & 83.85 & 1.95 \\
Zahrah \& Suryana (2019) & 84.95 & 0.93 \\
Ilham, et al. (2016) & 83.89 & 1.16 \\
Dewi, et al. (2020) & 83.97 & 1.42 \\
Saifuddin \& Nugraheni (2020) & 84.27 & 0.82 \\
Rahmawati \& Trimurtini (2020) & 86.00 & 1.78 \\
Zahrah \& Febriani (2020) & 84.95 & 0.93 \\
Hilman \& Astimar (2020) & 85.16 & 2.33 \\
Triani (2019) & 86.60 & 0.90 \\
Winarni (2017) & 86.94 & 1.71 \\
Nurhaliza (2019) & 87.20 & 1.47 \\
\hline & &
\end{tabular}

Based on Table 3, the highest effect size is 87.2 with a standard error of 1.47 . The lowest standard error is 0.51 , the lower the standard error, the lower the measurement error in research.

Table 4. Heterogenety Test

\begin{tabular}{lccc}
\hline & $\mathbf{Q}$ & df & p \\
\hline Omnibus test of Model Coefficients & 10095.643 & 1 & $<0.001$ \\
Test of Residual Heterogeneity & 552.412 & 43 & $<0.001$ \\
\hline
\end{tabular}

The heterogeneity test was conducted to prove that the data used had different effect sizes. The results of the heterogeneity test were carried out to determine the model to be used in calculating the summary effect (Karbono \& Retnawati, 2021). The results of the heterogeneity test are presented in Table 4.

The heterogeneity test used in this study was carried out with the parameter $\mathrm{Q}$ with degrees of freedom (df): $44-1=43$. The results of the heterogeneity test in Table 4 . indicate that the p value $<0.05$, because the $p$ value $<0.05$ then $\mathrm{H}_{0}$ rejected, which means that the effect size of each study is heterogeneous. The results of the study are heterogeneous in determining the summary effect calculation using the random effects model.

Table 5. Coefficients of Wald Test

\begin{tabular}{ccccc}
\hline & Estimate & Standard Error & $\mathbf{z}$ & $\mathbf{p}$ \\
\hline intercept & 79.252 & 0.789 & 100.477 & $<0.001$ \\
\hline
\end{tabular}

The analysis used in this study is the Random Effect model. This Effect Summary will provide an idea of the size of the observed effect. The results of the summary effect calculation using the random effects model are presented in Table 5. Table 5 shows that the effect size in this study was 79.25. This illustrates 

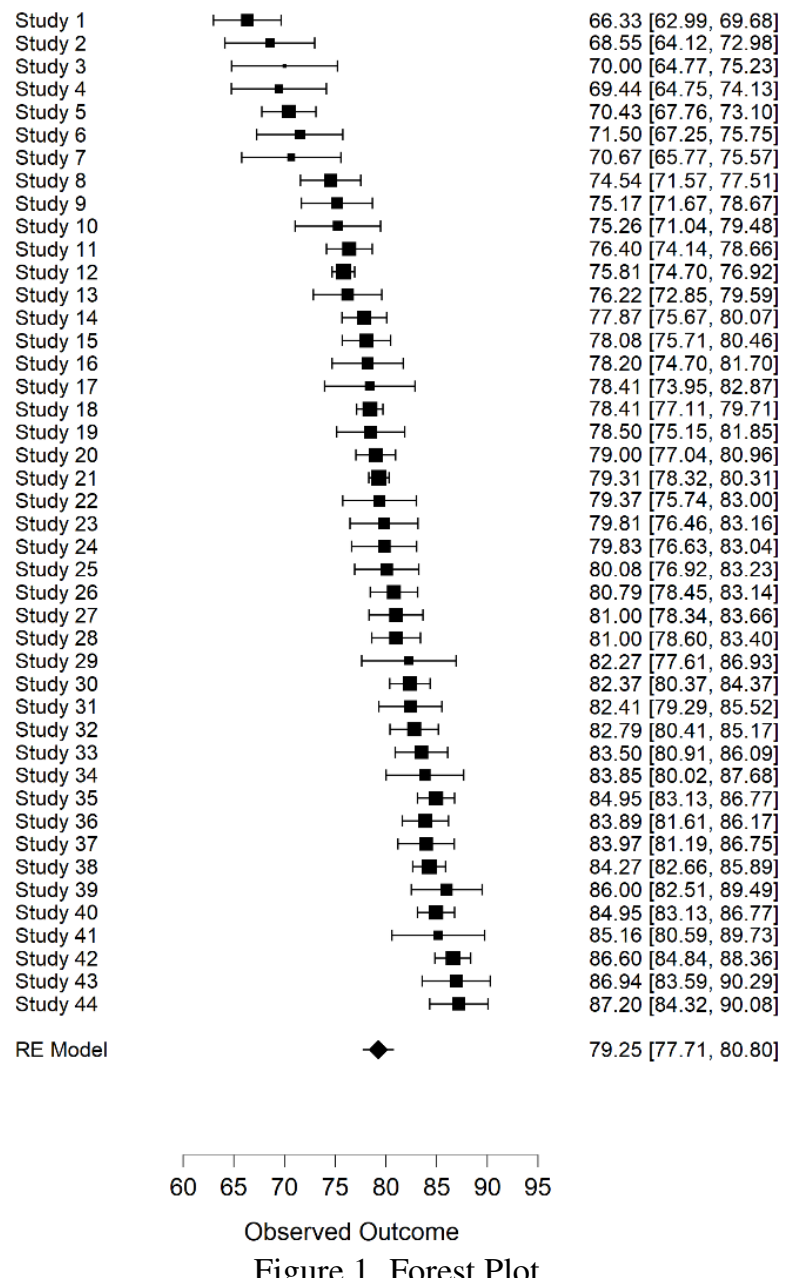

that learning with CTL can give good learning outcomes. Information about the effect size in each study is presented in Figure 1.

Figure 1 provides information on the summary effect distribution of each study. The distribution in each study varied from 66.33 to 87.20 . Then the effect summary with the random effects model shows that the magnitude of the effect size is 79.25 with a limit of 77.71 and discussed above 89.80 . Therefore, it can be concluded that contextual learning can provide learning outcomes with a value of more than 75 . Analysis of publication bias in this study used a funnel plot. Publication analysis can be used to prove that the metaanalysis carried out is objective and in accordance with empirical data. The publication results can be shown in Figure 2.

Based on the funnel plot image above, there is no visible circle in the funnel plot image of the fixedeffect model, so there is no missing research (Candra \& Retnawati, 2020), meaning that CTL has a relationship or influence on learning outcomes for elementary students. The results in Figure 2 prove that of the 44 studies that became subjects the distribution was symmetrically, so there was no potential for publication bias.

The results of the study prove that the proportion of students' scores by using the CTL is around 79.25 , and this result is sufficient as a student's mastery. The results of each study showed that 20 studies were below the aggregate average while the other 24 studies had an average above the aggregate. Conditions that support the use of CTL strategies are connections to real-world contexts (Glynn. \& Winter., 2004). The use of CTL in learning in elementary schools is a common practice applied by teachers. The application of CTL in elementary schools is unique because not many teachers apply CTL in thematic learning. Generally, teachers apply CTL based on subject areas in elementary school, so the characteristics of thematic learning in elementary school are not very visible. CTL practice conducted by Anggreni, et al. (2017) showed that learning using a 


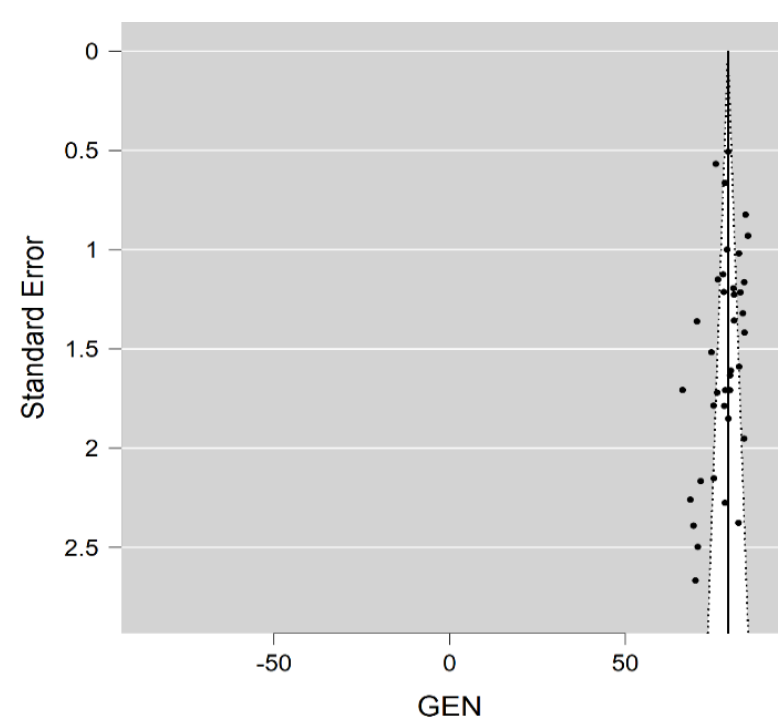

Figure 2. Funnel Plot

simple media-assisted contextual learning approach had an effect on students' mastery of science knowledge competencies compared to using conventional learning. The use of learning media in CTL is quite commonly done by teachers to become a tool to link learning with the environment around students.

The use of CTL needs to pay attention to the learning components and student learning environment. The development of media or CTL learning resources demands teacher creativity. Teachers need to be active in utilizing the school environment as a learning resource to be able to create innovative media and teaching aids so that students can use them to discover the concepts of the material that has been studied (Somayana, 2020). In addition, CTL needs to involve students actively during the learning process. Students need to experience themselves being actively involved by using as many elements of their senses as possible about what is being studied or their social environment both individually and in groups (Winarni et al., 2017).

The use of contextual learning in thematic learning can actually be an opportunity for teachers to design learning that is closer to the student's environment. Thematic learning with a contextual approach in the classroom can help students relate learning materials to real-world situations experienced in everyday life so that the material learned is more easily embedded in students' memories (Astuti et al., 2018). In addition, CTL makes students not awkward to ask questions so that students are easy to complete the material and students are happy when discussing groups because they can solve problems together (Sari et al., 2019).

\section{CONCLUSION}

The results of a meta-analysis study with a random effect model showed that the CTL had an effect size of 79.25. This value shows that the use of CTL in learning in elementary schools can produce scores above the national minimum completeness criteria. The use of CTL in elementary schools needs to pay attention to thematic learning and strive to be close to the child's environment. The implementation of CTL in SD can be used with various variations and media. The uniqueness of teaching in elementary schools with a variety of subjects taught by classroom teachers can provide more experience for teachers to identify what types of CTL can be used in classroom practice. In addition, CTL needs to actively involve students so that learning can be more constructive.

\section{REFERENCES}

Adviani, R., Marzuki, M., \& Halidjah, S. (2017). Pengaruh Pendekatan Kontekstual Terhadap Kemampuan Menulis Karangan Deskripsi di Sekolah Dasar. Jurnal Pendidikan dan Pembelajaran Katulistiwa, 6(4).

Anggreni, N., Negara, I., \& Darsana, I. (2017). Pengaruh Pendekatan Pembelajaran Kontekstual Berbantuan Media Sederhana Terhadap Penguasaan Kompetensi Pengetahuan IPA Siswa Kelas IV. Mimbar PGSD, $5(2)$. 
Anjani, L., Putra, K., \& Ardana, I. (2020). Pengaruh Model Pembelajaran Contextual Teaching and Learning Berbantuan Media Konkret Terhadap Kompetensi Pengetahuan IPA Siswa Kelas IV SD Gugus Kompyang Sujana Tahun Ajaran 2019/2020. Program Studi Pendidikan Guru Sekolah Dasar Universitas Pendidikan Ganesha.

Antari, N., Agustika, G., \& Suniasih, S. (2020). Pengaruh Contextual Teaching and Learning Berbantuan Media Audio Visual Terhadap Kompetensi Pengetahuan IPA Siswa Kelas V SDN Gugus I Kuta Utara Tahun Ajaran 2019/2020. Program Studi Pendidikan Guru Sekolah Dasar Universitas Pendidikan Ganesha.

Asniah, N., Sabri, T., \& Halidjah, S. (2020). Pengaruh Penerapan Pembelajaran Kontekstual Teradap Hasil Belajar Tematik Siswa Kelas V. Jurnal Pendidikan dan Pembelajaran Katulistiwa, 9(7).

Astuti, T., Kartono, K., \& Utami, S. (2018). Pengaruh Pendekatan Kontekstual Terhadap Hasil Belajar Tematik di SD. Jurnal Pendidikan dan Pembelajaran Katulistiwa, 7(9).

Astutik, S. (2021). Pengembangan Modul Pembelajaran Matematika dengan Pendekatan Kontekstual dalam Meningkatkan Hasil Belajar Peserta Didik Kelas V Sekolah Dasar Islam Qur'ani Al-Bahjah Karangrejo Tulungagung. IAIN Tulungagung.

Bumgarner, M. A. (2017). An Introduction to Contextualized Teaching and Learning: A Way to Teach Content through relevant materials that keeps students engaged and learning. Retrieved from https://slideplayer. com/slide/12187654

Candra, C., \& Retnawati, H. (2020). A Meta-Analysis of Constructivism Learning Implementation towards the Learning Outcomes on Civic Education Lesson. International Journal of Instruction, 13(2).

Dewi, A., Manuaba, I., \& Kristiantari, M. (2020). Pengaruh Model Contextual Teaching and Learning Berbasis Tri Kaya Parisudha Terhadap Kompetensi Pengetahuan IPA Siswa Kelas V SDN Gugus Viii Kecamatan Gianyar Tahun Ajaran 2019/2020. Program Studi Pendidikan Guru Sekolah Dasar Universitas Pendidikan Ganesha.

Farida, U., Agustini, F., \& Wakhyudin, H. (2017). Efektivitas Model Pembelajaran Scramble Berbasis Kontekstual Terhadap Kemampuan Berpikir Kritis IPS Siswa Kelas III SD Negeri Kebondalem 01 Batang. Jurnal Ilmiah Sekolah Dasar, 1(3), 192-199.

Fernando, S. Y., \& Marika, F. M. (2017). Constructivist Teaching/Learning Theory and Participatory Teaching Methods. Journal of Curriculum and Teaching, 6(1).

Framita, W., Krisnadi, H., \& Ulianti, E. (2018). Pengaruh Pembelajaran Kontekstual Terhadap Hasil Belajar Siswa Kelas III SDN 24 Pontianak Timur. Jurnal Pendidikan dan Pembelajaran, 7(9).

García, T., Rodríguez, C., González-Castro, P., González-Pienda, J. A., \& Torrance, M. (2016). Elementary students' metacognitive processes and post-performance calibration on mathematical problem-solving tasks. Metacognition and Learning, 11(2), 139-170.

Glynn., S., \& Winter., L. (2004). Contextual Teaching and Learning of Science in Elementary Schools. Journal of Elementary Science Education, 14(2), 51-63.

Harsanti, A. (2017). The Effectivenes of Contextual Teaching And Learning (CTL) Model Using Poster Towards Students Learning Outcomes in Social Science Subject of Class IV SDN Selotinatah Suburban Ngariboyo Magetan. Proceedings International Seminar of Primary Education, 1(1), 58-61.

Hasnidar, H., \& Elihami, E. (2020). Pengaruh Pembelajaran Contextual Teaching Learning terhadap Hasil Belajar PKn Murid Sekolah Dasar. Jurnal Pendidikan Guru Sekolah Dasar, 1(1).

Herfiani, H., \& Syarifuddin, S. (2018). Pengaruh Pendekatan Pembelajaran Contextual Teaching and Learning (CTL) terhadap Peningkatan Hasil Belajar Konsep Struktur dan Fungsi Bagian Tumbuhan Kelas IV SD. (JKPD) Jurnal Kajian Pendidikan Dasar, 3(1).

Hilman, A. Y., \& Astimar, N. (2020). Pengaruh Pendekatan Contextual Teaching and Learnig terhadap Hasil Belajar Kelipatan dan Faktor Bilangan di Kelas IV Sekolah Dasar. Jurnal Pendidikan Tambusai, 4(3), 2555-2559. doi:10.31004/jptam.v4i3.742

Ihsani, I., Prayitno, A., \& Shulkhah, S. (2018). Efektifitas Pembelajaran Contextual Teaching and Learning (CTL) dalam Meningkatkan Hasil Belajar Siswa pada Mata Pelajaran Matematika Kelas III di SD Islam Ar-Rahmat Weragati Majalengka. Program Studi Pendidikan Guru Madrasah Ibtidaiyah IAI Bunga Bangsa Cirebon.

Ilham, I., Khaeruddin, K., \& Saleh, S. (2016). Pengaruh Penerapan Pembelajaran Contextual Teaching and Learning (CTL) Terhadap Hasil Belajar Ipa Murid Kelas V SD Negeri Bontojai Kecamatan Tamalanrea Kota Makassar. Program Studi Pendidikan Guru Sekolah Dasar Universitas Muhammadiyah Makassar.

Johnson, E. B. (2008). Contextual Teaching and Learning. MCL. 
Kalchik, S., \& Oertle, K. M. (2010). The Theory and Application of Contextualized Teaching and Learning in Relation to Programs of Study and Career Pathways. Transition Highlights, (2).

Karbono, K., \& Retnawati, H. (2021). The Correlation between Religiosity and Multiple Intelligences: A MetaAnalysis. International Journal of Instruction, 14(1).

Khotimah, R., \& Masduki, M. (2016). Improving Teaching Quality and Problem Solving Ability Through Contextual Teaching and Learning in Differential Equations: A Lesson Study Approach. Journal of Research and Advances in Mathematics Education, 1(1).

Latifah, N., \& Sa'odah, S. (2019). Pendekatan Kontekstual Terhadap Kemampuan Literasi Bahasa Indonesia Siswa Kelas I Sekolah Dasar. Pedagogia: Jurnal Ilmiah Pendidikan Dasar Indonesia, 1(1). doi:10.28185/ pedagogia.v1i1.405

Mandasari, D., Warsono, W., \& Subroto, W. (2019). Pengembangan Bahan Ajar PKn Kelas V yang Berorentasi Pada Pendekatan CTL (Contextual Teaching and Learning) Untuk Meningkatkan Hasil Belajar Siswa Sekolah Dasar di SDN Lerpak 3 Bangkalan. Jurnal Review Pendidikan Dasar. Jurnal Kajian Pendidikan dan Hasil Penelitian, 5(2).

Mawardi, M., Wardani, N. S., Hardini, A. T. A., \& Kristin, F. (2019). Model Desain Pembelajaran Tematik Terpadu Kontekstual Untuk Meningkatkan Kebermaknaan Belajar Siswa SD. Scholaria: Jurnal Pendidikan dan Kebudayaan, 9(1), 48-61. doi:10.24246/j.js.2019.v9.i1.p48-61

Natalia, D., Asran, M., \& Kresnadi, H. (2017). Pengaruh Pendekatan Kontekstual Terhadap Hasil Belajar Siswa dalam PKn Kelas III SDN Se-Pontianak Kota. Jurnal Pendidikan dan Pembelajaran Katulistiwa, 6(11).

Nilasari, E., Djatmika, E., \& Santoso, A. (2016). Pengaruh Penggunaan Modul Pembelajaran Kontekstual terhadap Hasil Belajar Siswa Kelas V Sekolah Dasar. Jurnal Pendidikan: Teori, Penelitian, dan Pengembangan, $1(7)$.

Nurhaliza, E. (2019). Penerapan Model CTL (Contextual Teaching and Learning) Melalui Alat Peraga Torso dalam Peningkatan Hasil Belajar Pada Mata Pelajaran IPA Kelas V di SDN Muara Bumban 1 Kabupaten Murung Raya. Al-Mudarris: Jurnal Ilmiah Pendidikan Islam, 2(2), 220-240.

Nursanti, A., Putra, K., \& Manuaba, I. (2020). Pengaruh Pendekatan Contextual Teaching and Learning Berbasis Portofolio Terhadap Kompetensi Pengetahuan IPA Kelas V gugus Tuanku Imam Bonjol Kecamatandenpasar Barat Tahun 2019/2020. Program Studi Pendidikan Guru Sekolah Dasar Universitas Pendidikan Ganesha.

Nuryanto, R., Kresnadi, H., \& Hamdani, H. (2018). Pengaruh Pendekatan CTL Terhadap Hasil Belajar IPA Siswa Kelas IV Sekolah Dasar. Jurnal Pendidikan dan Pembelajaran Katulistiwa, 7(9).

Purwanti, S., Nuriman, N., \& Agustiningsih, A. (2017). Penerapan Model Pembelajaran Contextual Teaching and Learning (CTL) untuk Meningkatkan Motivasi dan Hasil Belajar pada Materi Energi Panas dan Bunyi Siswa Kelas IVB SDN Balunglor 03 Jember Tahun Ajaran 2016/2017. Program Studi Pendidikan Guru Sekolah Dasar Universitas Jember.

Puspitarini, Y., \& Hanif, M. (2019). Using Learning Media to Increase Learning Motivation in Elementary School. Anatolian Journal of Education, 4(2).

Qudsyi, H. (2017). Effectiveness of contextualized teaching and learning (CTL) Approach to Improve Student Achievement and Students' Self-Efficacy in Cognitive Psychology Course. Online.

Rahmawati, R., \& Trimurtini, T. (2020). Keefektifan Model Contextual Teaching and Learning Berbantuan Kubus Satuan terhadap Hasil Belajar Matematika Siswa Kelas V SDN Gugus Raden Saleh Semarang. Jurusan Pendidikan Guru Sekolah Dasar Universitas Negeri Semarang.

Retnawati, H., Apino, E., Kartianom, K., Djidu, H., \& Anazifa, R. (2018). Pengantar Analisis Meta. Yogyakarta: Parama Publishing.

Safitri, T., \& Trimurtini, T. (2020). Keefektifan Model Contextual Teaching and Learning Berbantuan Media Papan Berpaku terhadap Hasil Belajar Matematika Siswa Kelas IV SDN Gugus Tamansari Kebumen. Jurusan Pendidikan Guru Sekolah Dasar Universitas Negeri Semarang.

Saifuddin, A., \& Nugraheni, N. (2020). Keefektifan CTL dan PBL terhadap Kemampuan Pemecahan Masalah Matematika Siswa Kelas IV SDN Gugus Wijaya Kusuma Kecamatan Welahan Kabupaten Jepara. Jurusan Pendidikan Guru Sekolah Dasar Universitas Negeri Semarang.

Santoso, E. (2017). Penggunaan Model Pembelajaran Kontekstual untuk Meningkatkan Kemampuan Pemahaman Matematika Siswa Sekolah Dasar. Jurnal Cakrawala Pendas, 3(1).

Sari, W., Hamdani, H., \& Kresnadi, H. (2019). Pengaruh Pendekatan Kontekstual Terhadap Hasil Belajar Matematika Siswa Kelas IV Sekolah Dasar. Jurnal Pendidikan dan Pembelajaran Katulistiwa, 9(1). 
Satriani, I., Emilia, E., \& Gunawan, M. H. (2012). Contextual Teaching and Learning Approach to Teaching Writing. Indonesian Journal of Applied Linguistics, 2(1), 10-22.

Scans, S. (2000). A SCANS Report for America. Washington DC: Department of Labor.

Seifert, K., \& Sutton, R. (2009). Educational Psychology. Zurich: Jacobs Foundation.

Setiawan, A. (2020). Pengaruh Model Pembelajaran CTL (Contextual Teaching and Learning) Terhadap Hasil Belajar Siswa Pada Subtema 1 Tema 2 Kelas V SD N 1 Nusa Bakti Kecamatan Belitang III Kabupaten Oku Timur. Jurnal Edukasi Madrasah Ibtidaiyah, 2(2).

Somayana, W. (2020). Pengembangan LKS Berbasis Contextual Teaching and Learning pada Pembelajaran IPA Materi Daur Air Sekolah Dasar. Jurnal Pendidikan Indonesia, 1(4).

Sudira, N., Wiyasa, I., \& Putra, M. (2020). Pengaruh Pembelajaran Kontekstual Berbasis Multikultural Terrhadap Kompetensi Pengetahuan PPKN Siswa Kelas V SD Gugus VII Kecamatan Kuta Selatan Kabupaten Badung Tahun Ajaran 2019/2020. Program Studi Pendidikan Guru Sekolah Dasar Universitas Pendidikan Ganesha.

Tinja, Y., Towaf, S., \& Hariyono, H. (2017). Pengembangan Bahan Ajar Tematik Berbasis Kearifan Lokal Sebagai Upaya Melestarikan Nilai Budaya pada Siswa Sekolah Dasar. Jurnal Pendidikan: Teori, Penelitian, dan Pengembangan, 2(9).

Triani, D. A. (2019). PENGEMBANGAN BAHAN AJAR MATEMATIKA DENGAN PENDEKATAN KONTEKSTUAL UNTUK MENINGKATKAN HASIL BELAJAR SISWA. Factor M, 2(1). doi:10.30762/ f_m.v2i1.1690

Wahidah, S., Sari, Y., \& Jupriyanto, J. (2019). Pengaruh Model Kontekstual Terhadap Kemampuan Pemahaman Konsep Peserta Didik Kelas V SD Al Hikmah Semarang. Konferensi Ilmiah Mahasiswa Unissula, 2.

Winarni, E., Dadi, S., \& Lusa, H. (2017). Pengaruh Pembelajaran Tematik Terpadu Menggunakan Discovery Learning Terhadap Pengetahuan Siswa Sekolah Dasar Tentang Peninggalan Sejarah. JPD: Jurnal Pendidikan Dasar, l(1).

Wulandari, N., Kartono, K., \& Halidjah, S. (2019). Pengaruh Pendekatan CTL Terhadap Hasil Belajar Siswa Dalam Pembelajaran IPA Kelas V Pontianak Timur. Jurnal Pendidikan dan Pembelajaran Katulistiwa, $8(6)$.

Yesya, D., Desyandri, D., \& Elma Alwi, E. (2018). Pengaruh Penggunaan Model Contextual Teaching and Learning (CTL) dalam Pembelajaran Pkn Di Sekolah Dasar. Jurnal Inovasi Pembelajaran SD, 6(1).

Zahrah, R., \& Febriani, W. (2020). A Contextual Problem Based of Local Wisdom Improve The Ability to Solving A Word Problem Mathematics Students of Elementary School. Journal of Elementary Education, 4(1).

Zahrah, R., \& Suryana, Y. (2019). Pendekatan Contextual Teaching Learning (CTL) dalam Meningkatkan Kemampuan Menyelesaikan Soal Cerita Matematika Siswa Sekolah Dasar. Jurnal Tunas Bangsa, 6(1). 